\title{
EARLY HUNGARIAN INFORMATION ON THE BEGINNING OF THE WESTERN CAMPAIGN OF BATU (1235-1242)
}

\author{
ROMAN HAUTALA \\ University of Oulu, Finland \\ Pentti Kaiteran st., 1, 90570 Oulu, Finland \\ e-mail: virisequisque@hotmail.com
}

The author of this article examines the gradual accumulation of information in the Hungarian Kingdom about the Mongol Western Campaign and the corresponding propagation of this information in Western Europe. The primary information was brought to Europe by the Dominican friar Julian after his return from his travel to the Volga Magyars at the end of 1235. The letter of friar Julian written at the beginning of 1238 is replete with information about Mongol tactical warfare, previous military campaigns of Chingis Khan and Jochi, and the first Mongol conquest in the early stages of the Western Campaign of Batu. He also brought an oral report of the Prince of Vladimir on the Mongol plans to attack the Hungarian Kingdom. Soon the content of Julian's letter became known in Western Europe. The Hungarian King Béla IV started to make preparations for the imminent Mongol invasion and attempted to organise resistance.

Key words: Mongol Empire, Mongol Western Campaign, Hungarian mediaeval sources, Dominican missions to the East, ultimatums of the Mongol khans, eschatological perceptions of the Mongol invasions.

Judging by Riccardo of San Germano's report on the battle of Kalka (Garufi 1938, pp. 110-111), the first information about the Mongols arrived in Hungary through the Cumans. ${ }^{1}$ The deployment of the Catholic Apostolate among the nomads of southern Moldova, resulting in a rapprochement between the Cumans and the Kingdom of Hungary, must have contributed to influx of news on the approach of the Mongols.

${ }^{1}$ A native of San Germano (now Cassino) in the Italian region of Lazio, Riccardo assumed the position of notary in the financial administration of Emperor Frederick II of Hohenstaufen in 1214 (Garufi 1938, pp. iii-iv, xi-xii). At the time of writing his "Chronicle's" fragment referred to herein (1223), Riccardo was apparently in southern Italy performing various orders of the Emperor (Garufi 1938, p. xiii). Although there is also suggestion that he might have been in the Kingdom of Hungary (Schiel 2011, pp. 65-66, 69, note 120). 
This is evidenced by a meaningful letter of the Dominican Benedict addressed approximately in 1238 to Raymond of Penyafort, Master of the Order of Preachers (Pashuto 2011, p. 580; Altaner 1924, p. 144). ${ }^{2}$ However, the primary information about the beginning of the Mongol Western Campaign had not been brought to Europe by the Cumans but by the Dominican friar Julian after his return from his travel to the Volga Magyars at the end of $1235^{3}$

The eastern expedition of Julian was an obvious consequence of the missionary activities' extension by the Hungarian Dominicans encouraged by their proselytising success among the Cumans. According to Riccardus, the copyist of the report on the first eastern journey of Julian, ${ }^{4}$ the friars of the Dominican Province of Hungary decided to find the ancestral homeland of the western Hungarians out of compassion for the Eastern Hungarians who "remained in the sin of unbelief", according to a statement of the by now lost Hungarian chronicle, the so-called "primeval gesta" (Dörrie 1956, p. 151). ${ }^{5}$

${ }^{2}$ According to Benedict, the baptised Cumans manifested commendable devotion "both in the abstention from food during the Great Lent as well as in other Christian rituals" (tam in ieiuniis quadragesimalibus, quam alii christiani ritus observanciis). In general, the Dominican friar's letter reflected the nomads' desire to "follow the Catholic faith in every way" (fidem catholicam pro viribus imitantur). It is possible that the Cumans' conversion was based on their sincere desire to adhere to the Christian faith. But we should not disregard Benedict's indication of the Cumans' obvious concern about the approach of the Mongols and their fears that the Mongols intend to attack them in the near future (Reichert 1896, p. 309).

${ }^{3}$ All the known information about friar Julian has come down to us in only two reports on his missionary activity in the East (Dörrie 1956, pp. 151-161, 165-182), since he is not mentioned in other European sources.

${ }^{4}$ The notary Riccardus is not mentioned in parallel Latin sources. Denis Sinor tried to associate Riccardus with the eponymous notary frequently mentioned in the official documentation of the Emperor Frederick II of Hohenstaufen (Sinor 1977, Ch. XI, pp. 590, 601; see also Guéret-Laferté 1994, pp. 37-38). However, his hypothesis has several drawbacks. Firstly, this notary is not mentioned in the imperial acts after 1234, that is, the time of this report's writing (in early 1236: Klopprogge 1993, pp. 194-195). Secondly, the author of this report expresses obvious sympathy for the Pope Gregory IX, despite the existence of strained relations between the Apostolic See and the Emperor (Schiel 2011, pp. 65-66, note 109). The latter remark implies that Richardus was close to the Papal curia but not to the court of Frederick II as evidenced by the fact that his report was immediately included in the "Liber Censuum Romanae Ecclesiae" (Klopprogge 1993, pp. 194-195; Bigalli 1971, p. 13). All this, however, does not mean that Riccardus was in Italy at the time of compiling this report. Most probably he lived in Hungary and the reference to the fact that he was a "brother" may suggest that he belonged to the Dominican or, what is very likely, to Cistercian Order (Schiel 2011, pp. $65-66$, note 109 ).

5 The existence of this "primeval gesta", that must have been compiled in the late 11 th century, was proven by Hungarian research (Bóna 1994, p. 112; Macartney 1953, p. 87). However, the only source with the same name (Gesta Ungarorum) that has come down to us is the chronicle by Master P., an anonymous notary of the Hungarian King Béla III, who began to compile his Gesta Ungarorum "Deeds of the Hungarians" after 1192 and finished his work in the early 13th century (Bak-Rady-Veszprémy 2010, pp. xvii, xix, xxi, xxvi; Rady 2009, p. 1; Kontler 2002, pp. 43, 72; Makkai 1973b, p. 61; Iorga 1937, p. 53). Master P. places the ancestral home of the Hungarians beyond the Volga, calling it Dentumoger, and reports that the Magyars migrated to Hungary along the route: Volga-Suzdal-Kiev-Vladimir-Galich. Apparently, the Hungarian anonymous obtained information on Dentumoger's location from the merchants of Volga Bulgaria who often visited Hungary 
The first Dominican expedition directed to the Black Sea Region, apparently in the first half of 1231 (Richard 1998, pp. 28-29; Göckenjan-Sweeney 1985, p. 83, note 5; Dörrie 1956, pp. 138-139), was not successful. However, one member of the mission, "the priest by the name of Otto", brought back encouraging news about the existence of "Great Hungary" and its approximate location at the end of 1233 (Dörrie 1956, p. 152). The second Dominican expedition consisting of four Friar Preachers travelled from Hungary in the spring of 1234 and reached Matrega by sea in May of the same year (Dörrie 1956, pp. 161-162). After nearly two-month stay in Matrega (the consequence of which was the inclusion of the valuable entry containing the description of local residents (the Ziches) in Riccardus's report (Ostrowski 1998, p. 472; Göckenjan-Sweeney 1985, p. 84, notes 9-10; Sinor 1977, Ch. XI, p. 591, note 6), Friar Preachers went to the land of the Alans, where they had to linger for six months (because of this, Riccardus's report was enriched with even more valuable description of the Alans).

Riccardus explains the delay of the Dominicans in Alanya with closeness of the "Tartars" (Dörrie 1956, p. 154), thereby indicating that in 1234 the Mongols invaded the Polovtsian steppes located to the west of the Volga River but later returned to the Jochid domains for the winter. Therefore, in February 1235, two members of the Dominican expedition (Julian and another friar named Gerard) were able to continue their journey northward and reached the land of the Burtas in 37 days (Dörrie 1956, p. 155). From there, the Dominicans went to an unknown city where one of the two friars, Gerard, died broken with hardships. Thus, Julian found himself alone. Nevertheless, he was able to reach Bilyar, the capital of Volga Bulgaria, after he had hired a certain "Saracen priest" as servant (Dörrie 1956, p. 156). Finally, Julian met in Bilyar a "Hungarian woman" who explained to him how to get to the dwelling territory of the Volga Magyars.

Riccardus reported that "Great Hungary" was in "two days away" from Bilyar (Dörrie 1956, p. 157). However, he did not specify, in which direction the dwelling area of the Volga Magyars was located and what distance he meant by this expression (leaving researchers freedom for various interpretations ${ }^{6}$ ). In any case, Riccardus did

since the 10th century (Bak-Rady-Veszprémy 2010, pp. 4-7; Sinor 2002, p. 1162; Tatár 1996, p. 284; Sinor 1977, Ch. VIII, p. 537).

However, the Hungarian Dominicans were not familiar with this source for the following considerations. First of all, Master P. does not mention the name of "Great Hungary" indicated in the Riccardus report (Sinor 2002, p. 1162; Zimoni 2000, p. 19). Secondly, friar Julian, the only Dominican who reached the Volga Magyars (according to Riccardus's report), took the most direct route from "Great Hungary" to "Christian Hungary" specified by the Hungarian anonymous, only when returning to the West, on the advice of the Volga Magyars (Dörrie 1956, p. 10; Sinor 2002, p. 1159). In turn, the first Dominican missionaries who tried to find the original homeland of the Hungarians, resorted to the use of alternative travel guides of western sources (or some Hungarian chronicle that has not survived), which invariably placed the ancestral home of the Hungarians near the "Meotid marshes", that is, in the Azov Sea Region or, perhaps, in Ciscaucasia (Sinor 2002, pp. 1157-1158, 1162).

${ }^{6}$ Apparently, friar Julian found the Magyars somewhere in the Belaya River Basin (Antonov 2012, pp. 34, 71-73; Bendefy 1937, p. 7), although there are other interpretations about the location of their dwelling area (Napol'skix - Churakov 2009, p. 472; Zimoni 2000, p. 20; Richard 
not question the existence of "Great Hungary" and described the warm welcome rendered to Julian by the Volga Magyars who spoke a language which he could understand.

More important is the following reference to the "Tartar people" (Dörrie 1956, p. 157), under which Riccardus undoubtedly had in mind the nomads of the ulus of Jochi. According to Riccardus, initial relations between the Magyars and Mongols did not develop in the best way, which led to an open clash ending with the victory of the Magyars (Dörrie 1956, pp. 157-158). In his later letter of 1238, Julian reports that the Magyars' first confrontation with the Tartars took place 14 years before their subjugation (Dörrie 1956, p. 172), thereby allowing to specify the date of the first conflict: since the Volga Magyars were subjugated to the Chingisids in 1236, their first confrontation with the Tatars should have happened in 1222 .'

In this way, Riccardus's report supplemented with Julian's information specifies that the first attack of the Jochid troops on "Great Hungary" occurred during the Khwarezmian Campaign of Chingis Khan. This information contradicts the assertion of Rashid al-Din that Jochi terminated all military action after the capture of Gurganj in April 1221 thereby causing the wrath of Chingis Khan (Rashid al-Din 1960, pp. 78-79). However, the famous Persian chronicler showed a certain bias in the evaluation of Jochi's activities and his statement should not be taken literally (Togan 2002, p. 159). It is possible that Jochi evaded personal participation in hostilities (Allsen 1983 , p. 13), but the troops under his authority continued territorial expansion. So, Juzjāni reports that after the capture of Gurganj, Jochi continued advancing to the north (Juzjānī 1881, p. 1283; see also Antonov 2012, p. 152; Allsen 1983, p. 12), and Juvayni indicates the presence of the Jochid troops on the "Plain of the Qifchaq" at the time of the return of tümens under Sübedei and Jebe's command from their Western campaign (Boyle 1958, Vol. I, pp. xxv, 149; Scarcia 1991, p. 175; Tizengauzen 1941, p. 21; see also Allsen 1983, p. 13).

Also the earliest report on the diplomatic mission of John of Plano Carpini compiled by a certain Minorite C. de Bridia in the Franciscan convent of Cracow on 30th July 1247 (Richard 1977, p. 54; Szcześniak 1966, p. 374; Skelton-Marston-Painter 1965 , pp. 40, 42) provides important information on the Jochid military operations. In particular, C. de Bridia writes: "The third army, however, which marched west with Chingis Khan's son Jochi Khan, conquered first the country called Terkemen ${ }^{8}$, sec-

1998, p. 29, note 36; Kazakov 1997, p. 42; Golden 1990, p. 246; Makkai 1973a, p. 21; Bigalli 1971, p. 13; Macartney 1953, p. 87).

${ }^{7}$ In the same letter, Julian specifies the time of the Volga Magyars' subjugation to the Mongols by pointing to the fact that the third mission of the Dominicans sent from Hungary to the East at the beginning of 1236 (Richard 1998, pp. 28-29; Dörrie 1956, pp. 138-139) met refugees from "Great Hungary" (as well as from Volga Bulgaria) in the eastern reaches of the Vladimir-Suzdal principality in summer or early autumn of the same year (Dörrie 1956, p. 180; see also Boyle 1971, p. 56; Thackston 1999, p. 325; PSRL 1, col. 460).

${ }^{8}$ According to Juvaynī, around the time of the siege and capture of Jand in April 1220, a band of Turcoman nomads (the Ghuzz) rebelled against the Mongols and were suppressed by the forces of Taynal Noyan (Boyle 1958, Vol. I, pp. xiii, 90-91; Scarcia 1991, p. 112). 
ondly the Bisermins ${ }^{9}$, next the Kangits ${ }^{10}$, and lastly invaded the country of Cuspcas or Comania. The Comanians, however, joined forces with the whole nation of the Russians and fought the Tartars near two small rivers, one called Kalka and the other called Coniuzzu ... After this victory the Tartars began the return journey to their own country, and on the way conquered several countries to the north, for example the Bastarchos, or Greater Hungary" (Skelton-Marston-Painter 1965, p. 72). ${ }^{11}$

It is clear that C. de Bridia's informants (or more precisely of Benedictus Polonus, on which oral report a Polish Franciscan based his "Tartar Relation") not only pointed to the quite probable interaction between the Jochid military forces and divisions of Sübedei and Jebe on both sides of the Caspian Sea (Allsen 1983, p. 13; Skelton-Marston-Painter 1965, p. 46), but they also attributed to Jochi both an imaginary participation in the Battle of the Kalka and an equally improbable conquest of "Great Hungary". In the latter case, they probably had in mind Sübedei and Jebe's clash with the military forces of Volga Bulgaria in the region of Samara Luka in autumn 1223, which, in fact, resulted in a serious defeat of the Mongols (Tizengauzen 1884, pp. 27-28; Izmailov 2009a, p. 81). More important, however, is a reference of C. de Bridia to the fact that after the capture of Gurganj, the Jochid army continued military action against the Kangli: as a result of the conquest of the northern Aral region, and of a further offensive against the Kipchaks of the Volga-Ural interfluve, the Tatars could well face the Volga Magyars.

Julian's specification regarding the timing of the first clash between the Tartars and Magyars suggests that it occurred a year before the return of Sübedei and Jebe's tümens from the western Polovtsian steppes (cfr. Antonov 2012, pp. 151-153; Schiel 2011, p. 73, note 133; Göckenjan-Sweeney 1985, p. 89, note 30; Allsen 1983, p. 16). Thus, the Jochid troops were to continue uninterrupted military operations against the Magyars after Sübedei and Jebe's return to Mongolia as well: this is corroborated by Julian's indication that the Magyars waged continuous war with the Tartars until their subjugation (Dörrie 1956, p. 172).

In turn, Riccardus has an arbitrary explanation by claiming that the Mongols who have suffered defeat by the Magyars at the first encounter entered into a military alliance with them and "completely devastated fifteen kingdoms" (Dörrie 1956, pp. 157-158). This speculation of Riccardus obviously contradicts the information of friar Julian who reports in his letter of the beginning of 1238 that the Mongols did not only enter in an alliance with the Magyars, but also waged continuous war against

\footnotetext{
${ }^{9}$ Muslims, that is, Khwarizmians (Skelton-Marston-Painter 1965, p. 72, note 3).

${ }^{10}$ The Kangli's heartland was located in Qara-Qum, in the steppes north of the Aral Sea (Allsen 1983, p. 12).

${ }^{11}$ Tercius autem exercitus qui ad occidentem iuit cum Tossuc can, filio Cingis can, subiugauit primo terram que dicitur Terkemen, secundum Biserminos, postea Kangitas, ad ultimum intrauerunt terram Cuspcas. Comani autem coadunati cum Ruthenis omnibus pugnauerunt cum Tartaris iuxta duos riuulos - nomen unius Calc, alterius vero Coniuzzu ... Victis ergo istis Tartari redire ceperunt ad terras proprias et in reditu ceperunt ab aquilone quasdam terras, uidelicet Bastarchos id est Maiorem Hungariam (Önnerfors 1967, pp. xx, 15). An examination of the relations between the Bashkirs and Hungarians is beyond the scope of this article.
} 
them for fourteen years, until their subjugation in the fifteenth year of the conflict (Dörrie 1956, p. 172). Trying to partially justify the unauthorised insertion by Riccardus about joint conquests of the Magyars and Mongols, we can assume that at the time of Julian's arrival in "Great Hungary" (June 1235) he did not know about the permanent nature of the conflict between the Magyars and Jochids since the hostilities between them probably were conducted in the border areas of "Great Hungary".

In this context, it should also be mentioned that certain doubts have existed concerning the authenticity of Riccardus's report. These doubts are associated with the discrepancy between the description of the Magyars' relations with the Mongols contained both in this source and in the report on the second travel of friar Julian. Riccardus's report composed at the beginning of 1236 presents the Volga Magyars as allies of the Mongols, while in the next letter written at the beginning of 1238 (Sinor 2002, p. 1155; Richard 1998, p. 29), friar Julian reports that the Mongols had already conquered relatives of the Hungarian Dominicans. In particular, Denis Sinor pointed to the obvious discrepancy between Riccardus's indication that the Mongols entered into an alliance with the Magyars following the first military conflict, whereas friar Julian claimed two years later that the Mongols waged war against the Magyars for fourteen years and subjugated them in the fifteenth year of military conflict (Sinor 2002, p. 1161; Sinor 1977, Ch. XI, pp. 595-596; see also Antonov 2012, pp. $146-$ 147; Guéret-Laferté 1994, pp. 37-38).

To sum up, Sinor came to the conclusion that Riccardus did not simply made some changes to Julian's report about the discovery of "Great Hungary" (which is not in doubt), but invented the entire report basing his falsification both on Julian's letter of 1238 and the currently unknown report on the first Dominican expedition referred to at the beginning of Riccardus's report (Sinor 1977, Ch. XI, pp. 596, 598).

The most important consequence of these conclusions was the assumption by Sinor, who did not question the authenticity of Julian's letter of 1238 , that the Dominican missionaries never reached the Volga Magyars, while the existence of "Great Hungary" was invented by Riccardus (Sinor 2002, p. 1162; 1977, Ch. VIII, p. 534, Ch. XI, pp. 596, 598).

However, the apparent consistency of Sinor's reasoning contains a number of drawbacks. First of all, we can explain the discrepancy of representation of the Magyar-Mongol relations in two sources by the fact that the first observation of friar Julian contained in the Riccardus report were made in 1235 , that is, at the time when the military potential of Batu was still very limited. In turn, friar Julian wrote his letter of 1238 both after the main military potential of the Mongol Empire appeared in Eastern Europe and the corresponding subordination of the Magyars.

We should also add to the above a remark on Sinor's relatively forced interpretation of a brief mention by brother Julian of the protracted conflict between the Magyars and Mongols. According to Sinor, Julian's assertion (of 1238) that the Mongols were attacking the Magyars "for fourteen years and seized them on the fifteenth year" should be understood as a gradual and consistent conquest of the Magyar territories, which could not go unnoticed by Julian at the time of his arrival in "Great Hungary" in 1235. However, the verb "to attack" (expugno) rather points here to the 
border raids of the Jochid vanguards that were not able to overcome the resistance of the Magyars until the arrival of the main forces of the Mongol Empire in 1236.

Therefore, the hypothesis of Denis Sinor should be rejected as not sufficiently substantiated concerning his doubts about the authenticity of Riccardus's report. Returning to the analysis of his report, we should deal with an interesting information of friar Julian received from a certain "envoy of the Tartar leader" about the existence beyond the "Tartar land of very numerous people who were taller and bigger than all the peoples, with so big heads that they do not match the size of their body". ${ }^{12}$ Thus, friar Julian was aware both of the fact that the Mongol Empire was not limited to the "Tartar land", that is, to the ulus of Jochi and of the appearance of the Mongols, distinctly different (according to the ambassador or more likely to Richardus's interpretation) from the "Tartars" who had been already familiar to the Magyars. In addition, friar Julian learned that the "Tartars" were planning an offensive against "Alemania" (Germany), but they were waiting for reinforcements of both the Mongol troops from Persia $^{13}$ and more importantly, the main forces of the Empire. In fact Julian learned from a Tatar envoy (who obviously brought an ultimatum demanding a subjugation and portending the future attack) that the Mongols decided to "come out of their land to fight with all those who wish to resist them and to destroy all the kingdoms that they will be able to subdue". ${ }^{14}$ Apparently, this information displayed a historical decision to begin the Mongol Western Campaign made by the Chingisids at the general Quriltai of 1235, which prompted Julian to hastily return to Europe (Dörrie 1956, pp. 159-160). In turn, Riccardus's indication that Julian went way back on June 21 (Dörrie 1956, p. 162) suggests that the Quriltai of 1235 was to be held no later than his departure from "Great Hungary". 15

In addition to describing the Mordvins, the subsequent and extremely inconsistent account of a reverse route by friar Julian is interesting in connection with the statement that his return path ran through territory of Rus as well as with Riccardus's indication that this direction was given to Julian by the Magyars (Dörrie 1956, pp. 160161). The latter clarification of Riccardus suggests the presence of an idea among the Volga Magyars about the location of "western" Hungary, which was probably formed on the basis of information from Volga Bulgarian merchants who allegedly had visited the Hungarian Kingdom since the 10th century (Makkai 1973b, p. 41; Spinei 1986, p. 99).

According to Riccardus, friar Julian returned to Hungary on 27 December 1235 (Dörrie 1956, p. 160) and, apparently, immediately set about drawing up a writ-

\footnotetext{
${ }^{12}$ Ultra terram Thartarorum esset gens multa nimis omnibus hominibus altior et maior, cum capitibus adeo magnis, quod nullo modo videntur suis corporibus convenire (Dörrie 1956, pp. $158-159)$.

${ }^{13}$ Apparently, this was distorted information on the preparation of a full-scale Mongol invasion of Greater Armenia under the command of Chormaqan Noyon implemented in parallel with or even in the framework of the Western Campaign of Batu (May 1996, pp. 49-50, 52).

${ }^{14}$ De terra sua exire proponit, pugnaturi cum omnibus, qui eis resistere voluerint, et vastaturi omnia regna quecumque poterunt subiugare (Dörrie 1956, p. 159).

${ }^{15}$ Juvayn $\overline{1}$ implicitly indicates that this quriltai was held in the spring period (Boyle 1958, Vol. I, pp. xxxi, 196-197).
} 
ten report, possibly with the personal participation of Riccardus (see Schiel 2011, pp. 65-66, note 109), finishing it in early 1236 (Klopprogge 1993, pp. 194-195). It should be noted that, similarly to the case when he referred to his departure from "Great Hungary", Julian does not specify the year during which the described events occurred. To determine the date of Julian's first travel to the East (which has direct relevance to the justification of all the previous conclusions ${ }^{16}$ ), attention should be payed to the further activities of friar Julian that become known when reading the contents of his letter written in early 1238 (Dörrie 1956, pp. 165-182; Sinor 2002, p. 1155; Richard 1998 , p. 27, note 30, p. 29; Sinor 1977, Ch. XI, p. 597).

In his message, friar Julian reports that he subsequently went to Italy with the obvious intention to inform the Roman Curia about the results of his eastern mission. Julian's journey to Rome was going to happen along with the departure of another Dominican mission to the Volga Magyars (Richard 1998, pp. 28-29; Dörrie 1956, pp. 138-139). Four members of this mission reached the eastern edge of the Vladimir-Suzdal' principality where they met "some Hungarian pagans" who were forced to leave "Great Hungary" in connection with a full-scale invasion by the Mongols. According to friar Julian, these refugees sought asylum in the West and were willing to convert to Catholicism "just to get to the Christian Hungary". ${ }^{17}$ Therefore, the Friar Preachers abandoned the original intention to visit "Great Hungary" and focused on proselytism among the Magyar refugees. But Yuri Vsevolodovich, the Grand Duke of Vladimir, worried about the prospect of the spread of "Roman religion" in his domains, and expelled the Dominicans from his principality (Dörrie 1956, p. 180).

However, the Dominicans did not consider their mission accomplished and headed for the Ryazan principality with the intention to get a circuitous route to "Great Hungary" or (what was more likely) to deploy the proselytising activities among the Mordvins or even the Mongols. On their arrival in Ryazan, two members of the Dominican mission went to the land of Mordvins, but disappeared there since (as explained by friar Julian) the "leader of the Mordvins"18 surrendered to the Mongols at the time of the Dominican missionaries' visit (Dörrie 1956, pp. 180-181). Two other members of the mission tried in vain to learn the fate of their co-brothers by sending their interpreter after them, but he was killed by the Mordvins (Dörrie 1956, p. 181).

In turn, friar Julian went from Rome to the East after the departure of this third Dominican mission (Richard 1998, pp. 27-29; Dörrie 1956, pp. 138-139) having received prescription from Pope Gregory IX to resume proselytising activities among the Volga Magyars together with the possible assignment to gather information on the military actions of the Mongols (Klopprogge 1993, p. 195; Sinor 2002, p. 1157). Apparently, friar Julian had the authority of the Holy See representative since he was

${ }^{16}$ The dates indicated in this article differ from the dates adopted in the Hungarian secondary literature (cf. Zimonyi 2008; 2014; Balogh 2001; Györffy 1986; Latzkovits 1934). I take this opportunity to thank my anonymous reviewer for calling my attention to these important works.

${ }^{17}$ Libenter fidem catholicam recepissent, [et] dum versus Ungariam christianam venissent (Dörrie 1956, p. 180).

${ }^{18}$ More precisely, of the Moksha tribe (Antonov 2012, p. 172; Izmailov 2009b, pp. 146, 149, 156; Napol'skix - Churakov 2009, p. 474; Tatár 2005, pp. 296, 298). 
hosted by the Grand Duke Vladimir and received from Yuri Vsevolodovich not only a verbal warning about the Mongols' intention to attack the Hungarian Kingdom but also Batu's ultimatum addressed to the Hungarian monarch Béla IV (Dörrie 1956, pp. 177-179). An incoherent information contained in his letter complicates clarification of the further activities of friar Julian. Apparently, he reached the eastern borders of the Vladimir-Suzdal' principality and met there the Ruthenian, Bulgarian and Magyar refugees who informed him about the Mongol conquest of "Great Hungary" and the neighbouring lands (Dörrie 1956, p. 166). After he had ascertained the impossibility of visiting the land of the Volga Magyars, friar Julian most likely headed for Riazan'. However, the information contained in his letter cannot clarify whether he went there accompanied by the mentioned Dominicans or he joined this mission shortly after the arrival of the Friar Preachers in the Riazan' principality. In any case, friar Julian makes it clear that he went back from Riazan' and reached the Hungarian Kingdom through the Polovtsian steppes (Dörrie 1956, pp. 178, 181). But, more importantly, Julian went back to Hungary at the time when Batu's army was located at the borders of the Ryazan principality but had not yet invaded it (Dörrie 1956, pp. 173-174). Julian had to go from Ryazan a few months before its fall, more precisely, in September or October 1237 (Göckenjan-Sweeney 1985, p. 123, note 55; Dörrie 1956, p. 181).

Therefore, between December 27 (the date of his return from "Great Hungary") and early autumn of 1237, Julian had to travel from Hungary to Rome to inform Pope Gregory IX about the results of his first mission; return from Rome to Hungary to make his way from there to the east; reach the eastern limits of the Suzdal principality and visit Ryazan to go from there back to Hungary. Taking into account that in all of these departure points Julian had to intermit his travel for considerable stretches of time, it is unlikely that along with his extended visits to the Roman Curia, Julian would only have needed nine months to fulfill his second mission to the East. ${ }^{19}$ Hence, Julian could not return to Hungary from his first journey to the East at the end of 1236 (cf. Anninskij 1940, p. 72; Bendefy 1937, p. 19), but a year earlier. Accordingly, he had to leave "Great Hungary" on 21 June 1235, and his first journey from Hungary was to begin in spring 1234 (Dörrie 1956, pp. 161-162).

Thus, friar Julian was unable to pursue the prescribed proselytising activities in "Great Hungary". However, he successfully fulfilled his mission to collect information about the Mongol offensive, which he probably got both from the refugees from the East and local informants of the Vladimir-Suzdal' and Riazan' principalities. Julian's letter is replete with information about the Mongol tactical warfare (Dörrie 1956, pp. 176-177), previous military campaigns of Chingis Khan and Jochi (Dörrie 1956, pp. 169-172), and the first Mongol conquest in the early stages of the Western Campaign of Batu (Dörrie 1956, pp. 172-173). Moreover, Julian described the arrangement of Mongol troops on the eve of the attack on Eastern Rus' (Dörrie 1956, pp. 173-174) adding to this information on the parallel invasion of the Mongols in Transcaucasia (Dörrie 1956, p. 175). But the most important news brought by

\footnotetext{
${ }^{19}$ For comparison one can mention that Julian needed six months to get back to Hungary from the area of the Volga Magyars' habitat.
} 
friar Julian to Hungary was an oral report of the Prince of Vladimir on the Mongols' plans to attack the Hungarian Kingdom (Dörrie 1956, pp. 177-179) confirmed by both the contents of Batu's ultimatum (Dörrie 1956, p. 179) and eschatological interpretations of future events (Dörrie 1956, pp. 181-182). ${ }^{20}$

Obviously, the content of Julian's letter soon became known in Western Europe (Sinor 1977, Ch. IX, p. 518). So, Alberic de Trois-Fontaines mentioned in his "Chronicle" an unsuccessful Dominican mission to the Volga Magyars and linked the Transcaucasian campaign led by Chormaqan Noyan with the conquest of "Great Hungary" by the troops of Batu (Scheffer-Boichorst 1874, p. 942). Also the Mongol rulers were quick to inform the Western rulers about their aggressive intentions, namely the same Alberic de Trois-Fontaines speaks of an ultimatum of a certain "king of the Tartars" addressed to Frederick II Hohenstaufen in 1238 in which he demanded the Holy Roman Emperor's absolute submission to the Tatars (Scheffer-Boichorst 1874, p. 943). Identification of the "king of the Tartars" mentioned in this passage is hampered by the lack of further hints similarly to the case of an ultimatum addressed to the Hungarian King Béla IV a year earlier (Dörrie 1956, p. 179). Both documents could be equally composed either in the offices of Batu or the Great Khan Ögedei (Iurasov 2011, p. 55; Pochekaev 2009; Ostrowski 1998, pp. 473-474; Göckenjan-Sweeney 1985, p. 117, note 32; Sinor 1977, Ch. XI, pp. 594-595; Skelton-Marston-Painter 1965, p. 104; Pelliot 1949, p. 19).

However, at this juncture we should refer to an interesting detail contained in the Riccardus report which, to a certain extent, could help identify the author of the above two ultimata. Riccardus reports that a certain "envoy of the Tartar leader" informed the Volga Magyars and friar Julian, who was also present at the site, about the resolution of the general Quriltai of 1235 to launch the Western campaign (Dörrie 1956, pp. 158-159). As mentioned above, Riccardus undoubtedly designated by the term "Tartars" the nomads of the ulus of Jochi. This allows us to identify the mentioned "Tartar leader" as Batu. At the same time, the words of the envoy that the Mongols decided to "fight all those who wish to resist them" can be correlated with the preamble of a letter addressed to the Hungarian King Béla IV, in which an unnamed "Khan" claims that he was given the power to magnify all "subordinated and suppress the opposing". ${ }^{21}$ This comparison allows us to simultaneously assume that the envoy directed to the Volga Magyars was carrying a letter, the preamble of which was formally similar to that of the ultimatum which was later addressed to the Hun-

${ }^{20}$ In his letter Julian transmitted the Russian interpretation of pseudo-Methodius's "Revelation" identifying the Mongols with Midianites and Ishmaelites and foreshadowing their conquest of Rome on the eve of Last Things (PSRL 3, p. 61; Jackson 2010, p. 41; Jackson 2005, p. 147; Iurchenko-Aksenov 2002, pp. 135-136; Jackson 2001, p. 94; Burnett-Dalché 1991, p. 160; DeWeese 1978-1979, p. 52; Bigalli 1971, p. 16; Pashuto 1950, pp. 64-65).

${ }^{21}$ Ego, Chayn, nuncius regis celestis, cui dedit potentiam super terram subicientes mihi se exaltare et deprimere adversantes (Dörrie 1956, p. 179). The preamble of this letter was consistent with the content of the later ultimata of the Mongol khans demanding unconditional submission of the European rulers (Sinor 2002, pp. 1165-1166). 
garian monarch, and that the author of the two ultimata (as well as of the ultimatum addressed to Emperor Frederick II) was, apparently, Batu khan.

Another interesting example of the Western European spread of information about the Mongols obtained directly from the participants of the Western Campaign of Batu represents a report on interrogation of the "Tartar spies" sent by an anonymous Hungarian prelate to the Bishop of Paris in the autumn of 1239 (Luard 1865, pp. 324-325; Luard 1872-1883, Vol. VI, pp. 75-76; on the date of the compilation of this letter, see Jackson 2005, p. 145; Jackson 2001, p. 100). The letter of the Hungarian bishop is replete with information about Mongol weaponry and contains an interesting indication that the Mordvins subordinated to Batu were used as a shock force of the Mongol army. At the same time, the letter of the Hungarian prelate contains an interesting attempt to correct specific information obtained during the interrogation to render it more credible. In particular, the author of the letter considered it appropriate to emphasise that all the obtained information clearly pointed to the fact that the Mongols were descendants of the lost Jewish tribes (Jackson 2005, p. 143; Schmieder 2000, p. 281). ${ }^{22}$ Matthew of Paris, in another passage of his "Chronica Major" (Luard 1872-1883, Vol. IV, pp. 76-78), convincingly refuted the possible objections of his potential readers that might cast doubt on the British chronicler's assertion that the Mongol conquests were predicted by Peter Comestor in his "Scholastic History" (Luard 1872-1883, Vol. IV, p. 78, note 2).

Despite some distortion of information from the east, the Latin world was informed about the aggressive intentions of the Chingisids. Concerns about the imminent invasion by the Mongols caused the rise of anti-Semitic sentiments in Germany, which were based on the traditional prejudice towards Jews accused of potential propensity to aid the enemies of Christianity (Bloch 1907, pp. 89-90). ${ }^{23}$ Presentiment of future disasters also contributed to the emergence of a new prophecy of Hungarian origin, which received a wide circulation in Western Europe and enjoyed increasing popularity over the next centuries. ${ }^{24}$

${ }^{22}$ Obviously, the anonymous Hungarian prelate was an advocate of the eschatological interpretations of Peter Comestor who predicted the invasion of the Ten Lost Tribes on the eve of Last Things (Jackson 2005, p. 22; Jackson 2001, pp. 93-94; Ross 1963, p. 35; Cary 1956, pp. 18, $72-$ 73, 130-131; Anderson 1932, pp. 65-66, 70, 74, 78).

${ }^{23}$ Probably, the author of "Neuburg Continuation of the Marbach Annals" attributed to the Jews the pleasure associated with the Mongol conquests implying a kinship between the "Tartars" and the lost Jewish tribes, the latter having been invariably presented as harbingers of the End of the World in the eschatological interpretations of the Middle Ages (Jackson 2005, p. 143). On the other hand, the reason for such rumors could also be a certain excitement observed among the Jews in Central Europe in connection with the approach of the five thousandth year of Jewish era (which was in 1240) and the related expectations about the Messiah as well as the coming deliverance of the Jews from the Christian "yoke" (Menache 2010, pp. 256, 262, 265, 268; Jackson 2010, pp. 38-39; Jackson 2005, pp. 143-144; DeWeese 1978-1979, p. 72, note 14; Bezzola 1974, p. 23).

${ }^{24}$ According to one of the copies of the prophecy (manuscript of 1241 from the Benedictine Abbey of Ottobeuren, now preserved in the Library of the University of Innsbruck, HS. 187, fol. $2^{\mathrm{r}}$ ), its text appeared in a certain "Snusnyac" abbey of the Cistercian Order, not mentioned in other European sources. However, according to Robert Lerner, this text could only have been written in 
The growing threat of the Mongol invasion of Europe contributed to the rapprochement between Béla IV and the Polovtsian khan Küten in 1239. According to Master Roger, King Béla IV's rapprochement with the Polovtsian khan was a consequence of Küten's defeat which he suffered in a collision with the Mongols (BakRady-Veszprémy 2010, pp. ii, $136-138) .{ }^{25}$ Due to the fact that the troops of Batu "devastated most of his land" ${ }^{26}$, Küten khan was forced to seek refuge in Hungary and asked Béla IV to allow him and his subordinates to move into the territory of his kingdom. The Hungarian monarch accepted the request "with exceeding great joy"27 and solemnly met Küten on the Transylvanian border personally taking part in the baptism of the Polovtsian khan.

In an effort to present Béla IV's activities in the pre-Mongol period in the most favourable light (Bak-Rady-Veszprémy 2010, pp. xli, xliv-xlv), Roger emphasised the importance of the khan's baptism and justified the decision of the Hungarian king with his personal desire to convert the Polovtsians to the Christian faith. At the same time, the author of the Carmen miserabile ("Sorrowful Lament") did not hide the fact that the king was pleased with the significant replenishment of his kingdom with military forces with whom he could "fight with greater force and more vigorously", ${ }^{28}$ should war break out. Of course, the Polovtsian military support could play a decisive role in the looming conflict with the Mongols. However, the military potential of the nomads could also be directed against domestic opponents of the Hungarian crown, who expressed concern that Béla IV allowed the Polovtsians to move into Hungary to "oppress and confound" his political opponents (Bak-Rady-Veszprémy 2010, pp. vii, 146).

Roger indicates a series of local conflicts with the Polovtsians already in the course of their moving into the Kingdom of Hungary (Bak-Rady-Veszprémy 2010, pp. iii, 140). ${ }^{29}$ It is more important, however, that Küten's immigration to Hungary coincided with the strengthening of internal political struggle within the kingdom. ${ }^{30}$ An ambitious attempt of the king to centralise the monarchical power accompanied by confiscation of the vast estates of former supporters of his father led to the formation of a cohesive political opposition to Béla IV. The Hungarian "barons" reacted

Hungary around 1239 or 1240 and immediately sent to France, Germany, Italy, and Britain (Lerner 1983 , pp. $12-15,25-27,29-33)$.

${ }^{25}$ Al-Nuwayrī reports that the Mongol victory was facilitated by a feud between the Polovtsian tribes of Durut and Toksoba (Tizengauzen 1884, p. 541; Dosaev 2012, p. 231). However, the dating of the events described by the Mamluk author remains unclear because, according to alNuwayrī, the Mongols of this period were headed by Jochi (d. 1227).

${ }^{26}$ Magnam partem terre ipsius ... hostiliter destruxerunt (Bak-Rady-Veszprémy 2010, pp. ii, 137-138).

${ }^{27}$ Rex repletus est gaudio magno (Bak-Rady - Veszprémy 2010, pp. ii, 138).

${ }^{28}$ Contra eos [inimicos] cum eis fortius et durius dimicaret (Bak-Rady-Veszprémy 2010, pp. xii, 154).

${ }^{29}$ See also Chapter VIII, wherein Roger describes Béla IV's measures in this regard (BakRady - Veszprémy 2010, pp. vii, 146-148).

${ }^{30}$ During 1235-1239 Béla IV sent to all Hungarian counties his trusted commissioners to review all the royal donations made since the beginning of the 13th century (Kontler 2002, p. 77; Engel 2001, p. 98; Fügedi 1986, p. 44; Makkai 1973b, p. 58; Makkai 1990, p. 25). 
very disapprovingly to the emergence of the king's new allies who possessed significant military capabilities. Condemnation of the Hungarian monarch's decision resulted in confrontation between the political opposition and the new immigrants, which, in turn, led to an open conflict and the expulsion of the Polovtsians from the kingdom at the time when their military capabilities could have been extremely useful to repel the onslaught of the Mongols.

\section{References}

Allsen, T. T. (1983): Prelude to the Western Campaigns: Mongol Military Operations in the VolgaUral Region, 1217-1237. AEMA pp. 5-24.

Altaner, B. (1924): Die Dominikanermissionen des 13. Jahrhunderts. Forschungen zur Geschichte der kirchlichen Unionen und der Mohammedaner- und Heidenmission des Mittelalters. Habelschwerdt (Schles.), Frankes Buchhandlung.

Anderson, A. R. (1932): Alexander's Gate, Gog, and Magog, and the Enclosed Nations. Cambridge, MA, Medieval Academy of America.

Anninskij (1940) Аннинский, С. А.: Известия венгерских миссионеров XIII-XIV вв. о татарах и восточной Европе. Исторический архив (Москва-Ленинград) №. 3, pp. 71-112

Antonov (2012) Антонов, И. В.: Башкиры в эпоху средневековья. Очерки этнической и политической истории. Уфа, ИП Галиуллин Д.А.

Bak, J. M. - Rady, M. C. - Veszprémy, L. (eds) (2010): Anonymus and Master Roger: The Deeds of the Hungarians \& Epistle to the Sorrowful Lament upon the Destruction of the Kingdom of Hungary by the Tatars. Budapest-New York, Central European University Press.

Balogh, L. (2001): A mongol támadások a Volga-vidéki népek ellen (1222-1236) [Mongol attacks against the peoples of the Volga region]. In: Weisz B.-Balogh, L.-Szarka, J. (eds): Tanulmányok a középkorról. A II. Medievisztikai PhD-konferencia (Szeged, 2001. április 3.) elöadásai [Studies on the Mediaeval Age. Papers of the $2 \mathrm{nd} \mathrm{PhD}$ conference on Mediaeval studies (Szeged, 3 April 2001]. Szeged, Szegedi Középkorász Műhely, pp. 7-19.

Bendefy, L. (1937): Fr. Julianus utazásának kéziratos kútföi $=$ Fontes authentici itinera Fr. Iuliani illustrantes (Archivum Europae Centro-Orientalis 3). Budapest, Főbizományos Stemmer Ödön Könyvkereskedés és Antiquarium, pp. 1-52.

Bezzola, G. A. (1974): Die Mongolen in abendländischer Sicht (1220-1270): ein Beitrag zur Frage der Völkerbegegnungen. Bern, Francke Verlag.

Bigalli, D. (1971): I Tartari e l'Apocalisse. Ricerche sull'escatologia in Adamo Marsh e Ruggero Bacone. Firenze, La nuova Italia editrice.

Bloch, H. (ed.) (1907): Annales Marbacenses qui dicuntur Continuatione Neoburgensibus a. $1213-$ 1238. In: Bloch, R. (ed.): Scriptores rerum Germanicarum in usum scholarum ex Monumentis Germaniae historicis recusi. Vol. IX. Hannoverae et Lipsiae, Impensis Bibliopolii Hahnian, pp. 84-100.

Bóna, I. (1994): The Hungarian-Slav Period (895-1172). In: Barta, G. -Köpeczi, B. et al. (eds): History of Transylvania. Budapest, Akadémiai Kiadó, pp. 107-177.

Boyle, J. A. (tr.) (1958): 'Ala-ad-Din 'Ata-Malik Juvaini, The History of the World-Conqueror. 2 vols. Cambridge, MA, Harvard University Press.

Boyle, J. A. (1971): The Successors of Genghis Khan. Translation from the Persian of Rashīd alDīn by John Andrew Boyle. New York-London, Columbia University Press. 
Burnett, Ch.-Dalché, P. G. (1991): Attitudes towards the Mongols in Medieval Literature: The XXII Kings of Gog and Magog from the Court of Frederick II to Jean de Mandeville. Viator: Medieval and Renaissance Studies (Berkeley, CA) Vol. 22, pp. 153-167.

Cary, G. (1956): The Medieval Alexander. Cambridge, Cambridge University Press.

DeWeese, D. (1978-1979): The Influence of the Mongols on the Religious Consciousness of Thirteenth Century Europe. Mongolian Studies (Bloomington, IN) Vol. 5, pp. 41-78.

Dosaev (2012) Досаев, А. С. (пер.): Магистр Рогерий. Горестная песнь о разорении Венгерского королевства татарами. Санкт-Петербург, Издательство “Дмитрий Буланин”.

Dörrie, H. (1956): Drei Texte zur Geschichte der Ungarn und Mongolen: Die Missionsreisen des fr. Julianus O.P. ins Uralgebiet (1234/5) und nach Russland (1237): und der Bericht des Erzbischofs Peter über die Tartaren. Göttingen, Vandenhoeck \& Ruprecht.

Engel, P. (2001): The Realm of St. Stephen: A History of Medieval Hungary, 895-1526. LondonNew York.

Fügedi, E. (1986): Castle and Society in Medieval Hungary (1000-1437). Budapest, Akadémiai Kiadó.

Garufi, C. A. (1938): Ryccardi de Sancto Germano notarii Chronica. In: Garufi, C. A. (ed.): Rerum Italicarum Scriptores. Vol. VII/2. Bologna, Nicola Zanichelli.

Golden, P. B. (1990): The Peoples of the Russian Forest Belt. In: Sinor, D. (ed.): The Cambridge History of Early Inner Asia. Cambridge, UK-New York, Cambridge University Press, pp. $229-255$.

Göckenjan, H.-Sweeney, J. R. (1985): Der Mongolensturm: Berichte von Augenzeugen und Zeitgenossen, 1235-1250. Graz, Verlag Styria.

Guéret-Laferté, M. (1994): Sur les routes de l'Empire Mongol: ordre et rhétorique des relations de voyage aux XIII et XIV siècles. Paris, H. Champion.

Györffy (1986): Julianus barát és a napkelet fölfedezése. Válogatta, a bevezető tanulmányt és a jegyzeteket írta Györffy György. Fordította Györffy György és Gy. Ruitz Izabella [Friar Julian and the discovery of the East. Selection, introductory study and notes by György Györffy. Translated by György Györffy and Izabella Gy. Ruitz]. Budapest, Szépirodalmi Könyvkiadó.

Iorga, N. (1937): Histoire des Roumains et de la Romanité orientale. Volume III. Les fondateurs d'Etat. Bucarest, Imprimerie de l'état.

Iurasov (2011) Юрасов, М.: Восприятие венграми монголо-татар во время походов орд Бату в Европу. In: Маслов А. Н. - Кузнецов А. А. (ред.): Альманах по истории Средних веков и раннего Нового времени. Выпуск 2. Нижний Новгород, Нижегородский государственный университет им. Н. И. Лобачевского, pp. 51-69.

Iurchenko-Aksenov (2002) Юрченко, А. Г.-Аксенов, С. В.: Христианский мир и “Великая Монгольская империя”. Материаль франиисканской миссии 1245 года. Москва, Издательство “Евразия".

Izmailov (2009a) Измайлов, И.: Волжская Булгария накануне походов хана Бату. In: Усманов, М. А.-Хакимов, Р. С. (ред.): История Татар с древнейших времен в семи томах. Том III. Улус Джучи (Золотая Орда). XIII-середина XV в. Казань, Институт истории им. Ш. Марджани АН РТ, pp. 81-82.

Izmailov (2009b) Измайлов, И.: Походы в Восточную Европу 1223-1240 гг. In: Усманов, М. А.-Хакимов, Р. С. (ред.): История Татар с древнейших времен в семи томах. Том III. Улус Джучи (Золотая Орда). XIII-середина XV в. Казань, Институт истории им. Ш. Марджани АН РТ, pp. 133-160. 
Jackson, P. (2001): Christians, Barbarians and Monsters: The European Discovery of the World beyond Islam. In: Linehan, P.-Nelson, J. L. (eds): The Medieval World. London, Routledge \& Kegan Paul, pp. 93-110.

Jackson, P. (2005): The Mongols and the West, 1221-1410. Harlow, UK, Pearson Longman Publishing.

Jackson, P. (2010): Medieval Christendom's Encounter with the Alien. In: Muldoon, J. (ed.): Travellers, Intellectuals, and the World beyond Medieval Europe. Farnham, UK-Burlington, VT, Ashgate Publishing, pp. 31-54.

Juzjānī (1881): The Tabakat-i-Nasiri: A General History of the Muhammadan Dynasties of Asia Including Hindustan from A.H. 194 (810 A.D.) to A.H. 658 (1260 A.D.) and the Irruption of the Infidel Mughals into Islam. 2 Vols. Edited by H. G. Raverty. London, Gilbert \& Rivington.

Kazakov (1997) Казаков, Е. П.: Волжская Булгария и финно-угорский мир. In: Хакимов, Р. С. Казаков, Е. П. (ред.): Finno-Ugrica. Выпуск 1. Казань, Институт истории им. Ш. Марджани АН РТ, pp. 34-46.

Klopprogge, A. (1993): Ursprung und Ausprägung des abendländischen Mongolenbildes im 13. Jahrhundert: ein Versuch zur Ideengeschichte des Mittelalters. Wiesbaden, Otto Harrassowitz Verlag.

Kontler, L. (2002): A History of Hungary: Millennium in Central Europe. Hampshire, Palgrave Macmillan.

Latzkovits, L. (1934): Alberik világkrónikájának magyar adatai. Forrástanulmány [Hungarian data in Alberik's world chronicle. A study of source]. Szeged (Kolozsvári-szegedi értekezések a magyar mủvelödéstörténelem köréböl 23).

Lerner, R. E. (1983): The Powers of Prophecy. The Cedar of Lebanon Vision from the Mongol Onslaught to the Dawn of the Enlightenment. Berkely-London, University of California Press.

Luard, H. R. (ed.) (1865): Annales monastici. Vol. II. Annales monasterii de Wintonia (A.D. 5191277); Annales monasterii de Waverleia (A.D 1-1291). London, Longman, Roberts, and Green.

Luard, H. R. (ed.) (1872-1883): Matthaei Parisiensis, monachi Sancti Albani, Chronica majora. 7 vols. London, Longman Publishing.

Macartney, C. A. (1953): The Medieval Hungarian Historians: A Critical and Analytical Guide. Cambridge (UK), Cambridge University Press.

Makkai, L. (1973a): The Origins of the Hungarian People and State. In: Barta, I.-Berend, T. I.Hanák, P. - Lackó, M. - Makkai, L. - Nagy, Zs. L. - Ránki, G. (eds): A History of Hungary. Budapest, Corvina Press, pp. 13-28.

Makkai, L. (1973b): The Independent Hungarian Feudal Monarchy to the Battle of Mohács (10001526). In: Barta, I. - Berend, T. I. - Hanák, P. - Lackó, M. - Makkai, L. - Nagy, Zs. L. - Ránki, G. (eds): A History of Hungary. Budapest, Corvina Press, pp. 29-118.

Makkai, L. (1990): Transformation into a Western-Type State, 1196-1301. In: Sugar, P. F.Hanák, P. - Frank, T. (eds): A History of Hungary. London, Tauris, pp. 23-33.

May, T. (1996): Chormaqan Noyan: The First Mongol Military Governor in the Middle East. Master's Thesis. Indiana University.

Menache, S. (2010): Tartars, Jews, Saracens and the Jewish-Mongol Plot of 1241. In: Muldoon, J. (ed.): Travellers, Intellectuals, and the World beyond Medieval Europe. Farnham, UKBurlington, VT, Ashgate Publishing, pp. 247-269.

Napol'skix - Churakov (2009) Напольских, В. - Чураков, В.: Финно-угорские народы Среднего Поволжья и Предуралья к началу ХІІІ в. In: Усманов, М. А.-Хакимов, Р. С. (ред.): 
История Татар с древнейших времен в семи томах. Том III. Улус Джучи (Золотая $O p д a)$. XIII-середина $X V$ в. Казань, Институт истории им. Ш. Мраджани АН РТ, pp. 470-477.

Ostrowski, D. (1998): City Names of the Western Steppe at the Time of the Mongol Invasion. BSOAS Vol. 61, No. 3, pp. 465-475.

Önnerfors A. (ed.) (1967): Hystoria Tartarorum C. de Bridia monachi. Berlin, De Gruyter.

Pashuto (1950) Пашуто, В. Т.: Очерки по истории Галиико-Волынской Руси. Москва, Издательство Академии Наук СССР.

Pashuto (2011) Пашуто, В. Т.: Половецкое епископство. In: Мельникова, Е. А. (ред.): Русь. Прибалтика. Папство. Избранные статьи. Москва, Русский Фонд Содействия Образованию и Науке, pp. 573-581.

Pelliot, P. (1949): Notes sur l'histoire de la Horde d'Or: suivies de quelques noms turcs d'hommes et de peuples finissant en "ar ». Ouvres posthumes de Paul Pelliot publiées sous les auspices de l'Académie des Inscriptions et Belles-Lettres et avec le concours du Centre National de la Recherche Scientifique. Vol. II. Paris, Librairie d'Amérique et d'Orient, Adrien Maisonneuve.

Pochekaev (2009) Почекаев, Р. Ю.: К вопросу о “переписке” Батыя и императора Фридриха II в период монгольского нашествия на Европу. In: Дьяков, Н. Н.-Зеленев, Е. И. (ред.): Востоковедение и африканистика в диалоге иивилизаций. ХХV Международная конференция "Источниковедение и историография стран Азии и Африки”. 22-24 апреля 2009. Тезисы докладов. Санкт-Петербург, рр. 345-346.

PSRL 1: Полное собрание русских летописей. Том первый: Лаврентьевская летопись. Карский, Е. Ф. (ред.). Ленинград, Издательство Академии Наук СССР, 1926-1928.

PSRL 3: Полное собрание русских летописей. Том 3. Новгородская первая летопись старшего и младмего изводов. Насонов, А. Н. (ред.). Москва-Ленинград, Издательство Академии Наук СССР, 1950.

Rady, M. (trans.) (2009): The Gesta Hungarorum of Anonymus, the Anonymous Notary of King Bela, pp. 1-71. - http://discovery.ucl.ac.uk/18975/1/18975.pdf.

Rashid al-Din (1960) Рашид ад-Дин: Сборник летописей. Том 2. Верховский, Ю. П.-Петрушевский, И. П. (ред.). Москва-Ленинград, Издательство Академии Наук СССР.

Reichert, B. M. (ed.) (1896): Monumenta ordinis fratrum praedicatorum historica. Vol. I. Fratris Gerardi de Fracheto O.P. Vitae Fratrum Ordinis Praedicatorum: necnon Cronica Ordinis ab anno MCCIII usque ad MCCLIV. Lovanii, Typis E. Charpentier \& J. Schoonjans.

Richard, J. (1977): Sur le pas de Plancarpin et de Rubrouck: La lettre de Saint Louis à Sartaq. Journal des Savants (Paris, Académie des inscriptions \& belles-lettres) Vol. 1, pp. 49-61.

Richard, J. (1998): La Papauté et les missions d'Orient au Moyen Age (XIII $-X V^{e}$ siècles). Rome, École Française de Rome.

Ross, D. J. A. (1963): Alexander Historiatus: A Guide to Medieval Illustrated Alexander Literature. London, Warburg Institute, University of London.

Scarcia, G. R. (tr.) (1991): Juvaini. Gengis Khan il conquistatore del mondo. Milano, Arnoldo Mondadori Editore.

Scheffer-Boichorst, P. (ed.) (1874): Chronica Albrici monachi Trium Fontium, a monaco Novi Monasterii Hoiensis interpolata. In: Pertz, G. H. (ed.): Monumenta Germaniae Historica, Scriptores. Vol. XXIII. Hannover, Bey den Brüdern Hahn, pp. 631-950.

Schiel, J. (2011): Mongolensturm und Fall Konstantinopels: Dominikanische Erzählungen im diachronen Vergleich. Berlin, Akademie Verlag. 
Schmieder, F. (2000): Tartarus valde sapiens et eruditus in philosophia. La langue des missionnaires en Asie. In: L'étranger au Moyen Âge: XXX Congrès de la SHMES (Göttingen, juin 1999). Paris, Publications de la Sorbonne, pp. 271-281.

Sinor, D. (1977): Inner Asia and Its Contacts with Medieval Europe. London, Variorum Reprints.

Sinor, D. (2002): Le rapport du Dominicain Julien écrit en 1238 sur le péril mongol. Comptes-rendus des séances de l'Académie des inscriptions et belles-lettres (Paris, Académie des inscriptions \& belles-lettres) Vol. 146/4, pp. 1153-1168.

Skelton, R. A.-Marston, T. E.-Painter, G. D. (1965): The Vinland Map and the Tartar Relation. New Haven, Yale University Press.

Spinei, V. (1986): Moldavia in the 11th-14th Centuries. Bucharest, Editura Academiei Republicii Socialiste România.

Szcześniak, B. (1966): Notes and Remarks on the Newly Discovered Tartar Relation and the Vinland Map. JAOS Vol. 86, No. 4, pp. 373-376.

Tatár, M. M. (1996): The Iranian Name of the Burtas People in the Hungarian Sources and Their Finno-Ugric Connections. In: Leskinen H.-Maticsák S. - Seilenthal T. (eds): Congressus Octavus Internationalis Fenno-Ugristarum. Jyväskylä 10.-15.8.1995. Pars V. Sessiones sectionum Lexiologia \& Onomastica. Jyväskylä, Moderatores, pp. 282-288.

Tatár, M. M. (2005): Ethnic Continuity by the Volga: From Vidini to Vet'ke. In: Haug, D. - Welo, E. (eds): Haptačahaptäitiš: Festschrift for Fridrik Thordarsson on the Occasion of His 77th Birthday. Oslo, Novus Forlag, pp. 289-308.

Thackston, W. M. (1999): Rashiduddin Fazlullah's Jami 'u't-tawarikh. (Compendium of Chronicles). A History of the Mongols. Part two. Translated and annotated by W. M. Thackston, Cambridge, Harvard University, Department of Near Eastern Languages and Civilizations.

Tizengauzen (1884) Тизенгаузен, В. Г.: Сборник материалов, относящиихя к истории Золотой Opды. Том 1. Извлечения из сочинений арабских. Санкт-Петербург, Типография Императорской Академии Наук.

Tizengauzen (1941) Тизенгаузен, В. Г.: Сборник материалов, относящихся к истории Золотой Орды. Том 2. Извлечения из персидских сочинений. Ромаскевич, А. А.-Волин, С. Л. (ред.). Москва-Ленинград, Издательство Академии наук СССР.

Togan (2002) Тоган, И.: Джучи хан и значение осады Хорезма как символы законности. In: Усманов, М. А. и др. (ред.): Источниковедение истории Улуса Дюуучи (Золотой Орды). От Калки до Астрахани 1223-1556. Казань, Мастер Лайн, pp. 146-187.

Van Cleve, T. C. (1972): The Emperor Frederick II of Hohenstaufen: immutator mundi. Oxford, Oxford University Press.

Zimoni (2000) Зимони, И.: Венгры в Волжско-Камском бассейне? In: Хакимов, Р. С. - Казаков, Е. П. (ред.): Finno-Ugrica. Выпуск 1. Казань, Институт истории им. Ш. Марджани АН PT, pp. 5-41.

Zimonyi, I. (2008): A mongolok nyugati hadjáratai [The western campaigns of the Mongols]. In: Zimonyi, I. (ed.): Középkori nomádok - korai magyarok [Mediaeval nomads - early Hungarians]. Budapest, Balassi Kiadó (Magyar Östörténeti Könyvtár 27), pp. 167-189.

Zimonyi, I. (2014): The Mongol Campaigns against Eastern Europe. In: Zimonyi, I. - Spinei, V. (eds): Medieval Nomads in Eastern Europe. Collected Studies. Bucureşti-Brăila: Editura Academiei Române-Muzeul Brăilei Editure Istros (Florilegium magistrorum historiae archaeologiaeque Antiquitatis et Medii Aevi 16), pp. 325-352. 
